\title{
Promoting Energy Efficiency in the Palestinian Municipalities: A Case Study of Al-Dahriya Municipality
}

\author{
Husain Alsamamra ${ }^{*}$, Iyad Isaila², Jawad Shoqeir ${ }^{3}$ \\ ${ }^{1}$ Al-Quds University, Department of Physics, Jerusalem, Abu-Dies, Palestine \\ ${ }^{2}$ Renewable Energy and Sustainability Joint Master Program, Al-Quds University, Jerusalem, Abu-Dies, Palestine \\ ${ }^{3}$ Al-Quds University, Department of Earth and Environmental Sciences, Jerusalem, Abu-Dies, Palestine \\ Email: ^hsamamra@staff.alquds.edu
}

How to cite this paper: Alsamamra, $\mathrm{H}$, Isaila, I. and Shoqeir, J. (2021) Promoting Energy Efficiency in the Palestinian Municipalities: A Case Study of Al-Dahriya Municipality. Smart Grid and Renewable Energy, 12, 17-29.

https://doi.org/10.4236/sgre.2021.122002

Received: January 9, 2021

Accepted: February 22, 2021

Published: February 25, 2021

Copyright (c) 2021 by author(s) and Scientific Research Publishing Inc. This work is licensed under the Creative Commons Attribution International License (CC BY 4.0).

http://creativecommons.org/licenses/by/4.0/

\begin{abstract}
Energy demand overall the world increases rapidly in various sectors, one of the highest energy consumption sector is the building sector. Installation of PV systems is one of the solutions to cover this demand and will serve in promoting energy efficiency in the Palestinian municipalities in decreasing the electricity bill, and using the saved money in constructing new projects and improving the level of services provided to citizens. In this work, Al-Dahriya municipality has been taken as a case study. The municipality installed $20 \mathrm{KW}$ of photovoltaic panels on the roof of the main building in 2015. The cumulative values for one year after installation the PV system represent a total consumed electricity by the main building was $71,506 \mathrm{kw}$, while the total generated power by the PV system that transferred to building was 32,664 kw, and $5323 \mathrm{kw}$ exported to the grid with total generated power by PV system was $37,987 \mathrm{kw}$. The participation of energy that produced by the photovoltaic system is $53.12 \%$ of the total power demand of the building. The value of generated power varies between the summer months and winter months through the difference of the solar radiation intensity and the number of shinning hours, the largest reading of solar radiation intensity is in the summer months. The study ensures the importance of applying selected thermal insulation materials in order to decrease the heat transfer through the boundary wall of the building. Furthermore, this study covers the other buildings and utilities of municipality and recommended with certain issues in order to promote energy efficiency.
\end{abstract}

\section{Keywords}

Energy Efficiency, Photovoltaic Panels, Thermal Insulation, Al-Dahriya 
Municipality

\section{Introduction}

The population overall the world is growing rapidly, this growth is associated with the development for a huge number of sectors, development in industry, technology, economy, service, commercial, and agriculture sector, this development requires more energy. Traditional sources of energy have a significant harmful effect on the environment and human through emission of $\mathrm{CO}_{2}$. Natural gas and oil that used in electricity generation, heating and cooling in buildings have a big participation in generation of $\mathrm{CO}_{2}$ emissions [1]. Renewable energy can supply two-thirds of the total global demand, and significantly participating in decreasing $\mathrm{CO}_{2}$ emissions for the coming three decades [2].

Palestine imports $100 \%$ of its fossil fuel from other countries about $87 \%$ of its electricity imports [3]. In addition, high population growth, high living standards and rapid industrial progress have led to an increase in energy demand in Palestine recently. Total energy consumption per citizen in Palestine is the lowest in the region ( 0.79 megawatt hours per year for citizen) and costs more than anywhere else compared to the countries of the Middle East. So, it is necessary to generate electricity from renewable energy resources in order to solve this insecure situation.

One of the main institutions which has an impact on human services is the local organizations or municipalities. The Palestinian municipalities are like all municipalities overall the world who concern in supplying services in the regions that belong to it, these services contain the supplying of water, electricity, collecting solid waste, and other services. Few Palestinian municipalities supply the electricity, while the most of municipalities depend on the electricity distribution companies that working in the region. The weakness of Palestinian municipalities due to the lack of resources is affecting on the potential of municipalities to construct the projects and decreasing the ability for investments. That also has its impact on the commitment of municipalities to pay the electricity bill to the electricity supplier. The value of bill is directly proportional to the amount of consumed electricity which depends on the number of employees and users, the total area and number of buildings and utilities, the nature of building materials that used in the construction of the building, and properties of used instruments and devices in the buildings.

Al-Dahriya municipality has been chosen as a case study to carry out this work due to some reasons: the classification of Al-Dahriya municipality as a large municipality which has six utilities, and more than 100 employees. Al-Dahriya municipality has installed the photovoltaic boards on the roof of the main building, which enables us to study the impact of using this PV system on the main building in order to save the electricity bill, and comparing the saving of 
power between the main building and other utilities. Al-Dahriya town located in the southern part of the West Bank $31^{\circ} 24^{\prime} 35^{\prime \prime} \mathrm{N}, 34^{\circ} 58^{\prime} 24^{\prime \prime} \mathrm{E}$, as shown in Figure 1 , with the semi-desert climate make it one of the most suitable locations for applying solar power systems as a part of successful renewable energy resources.

\section{Promoting Energy Efficiency in the Buildings}

The term "promoting energy efficiency in the buildings" meaning that the achieving of the minimum sufficient limit of power in order to manage and operate that buildings or utilities for the various aspects including lighting system, power system, HVAC system, and control system [4]. Achieving all of that by the minimum possible cost. Promoting energy efficiency can be achieved by applying some of particular measures, Smart control of lighting systems, the using of suitable construction materials and selected insulation materials, led lights, increasing the awareness of employees regarding the perfect usage of utilities, and using renewable energy resources, these are the most common used measures to achieve more efficient power. A lot of municipalities have been started retrenchment in order to do balance between incomes and spends. Because of the electricity bill is one of the highest costs, big efforts must be done to decrease the value of electricity bill through what we call "promoting energy efficiency in the buildings belong to the municipality". Applying the concept of energy efficiency leads to decrease the municipalities expend on the electricity bill, and able the municipalities to use that saved money in constructing new projects and Improving the level of services provision to citizens. Increasing the energy efficiency in residential, commercial, and industrial sectors can reduce air pollution emissions and greenhouse gases significantly [5]. Several studies have been discussed the promoting of energy efficiency from different points of view. Vigna, et al. 2018 [6] presented that, the physical connection to the same grid of building clusters allows the exchange of energy between buildings (e.g. PV panels installed in one building produce energy that can be used also by the other buildings) or from a central source toward the buildings (e.g. district heating). While, Allouhi, et al. 2015 [7] highlights on the buildings thermal regulation, called also thermal codes, which are a set of legal and mandatory requirements for building design and their compliance provisions during the construction period aiming at promoting energy performance of buildings. Another study [4] showed that the transitioning from conventional energy systems is not a change of technology only but also requires shifts in societal practices, institutions, and conventional governance models. The energy policy includes the suitable planning and the effective design in order to get the appropriate solution for the needed energy efficiency [8]. The study conducted by [9] states that applying energy efficiency methods will increase the added value to the building in the financial studies. Maidment, et al. 2014 [10] studied the impact of applying energy efficiency on the public health of the residents, the study founded that there is a small but significant improvement in the health after applying some of measures like thermal insulation, double glazing windows, and central heating. 


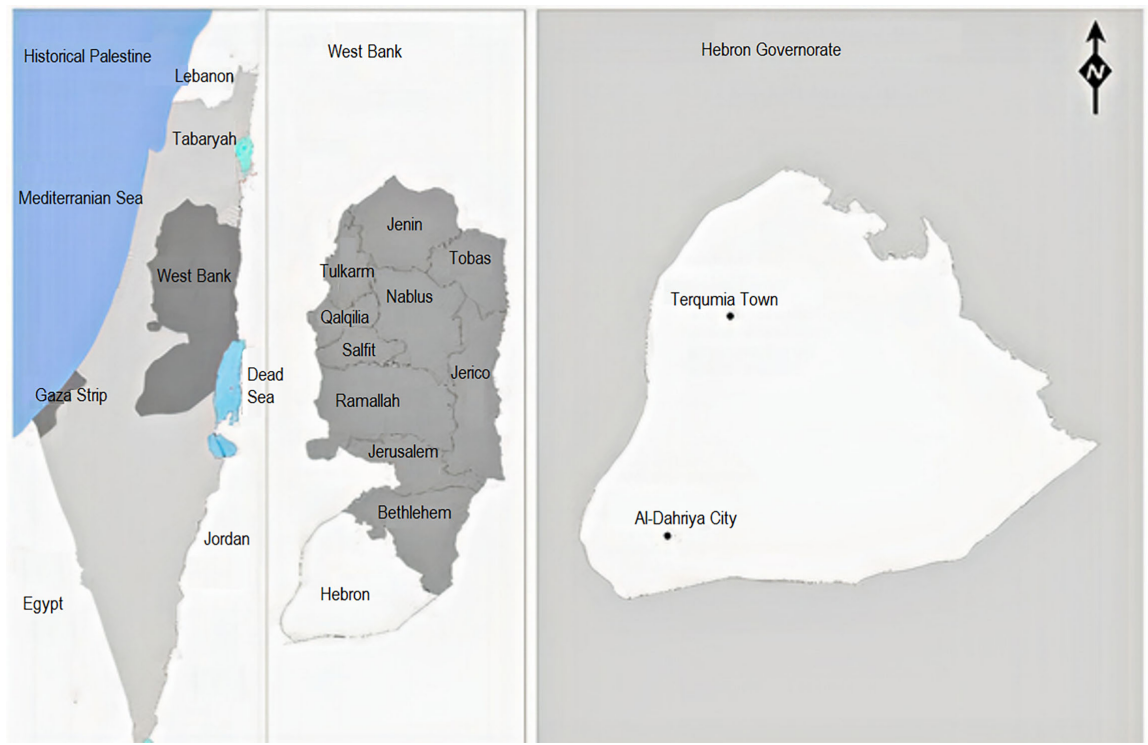

Figure 1. Location of Al-Dahriya Town.

\subsection{PV Systems}

Solar energy is one of the most widely-used renewable energy sources, this energy generated by the sun has been used to provide electricity for many years [11]. The best renewable energy system that could be used in Palestine is the solar system, Palestine is considered as a country of high solar energy potential since the daily average of solar radiation intensity in it amounts to $5.4 \mathrm{kWh} / \mathrm{m}^{2}$-day. This value is very encouraging to exploit this energy as far as possible [12]. The solar energy system in Al-Dahriya municipality was installed in 2015 as a project funded by Municipal Development and Lending Fund (MDLF), the photovoltaic panels that have been installed on the roof of the main building consists of 64 photovoltaic panels that arranged in three groups, the first group which located in the first level of the roof contains 16 photovoltaic panels, the second group located in the second and third level of the roof contains 32 photovoltaic panels, and the last group located in the last level of top roof with 16 photovoltaic panels. The 64 photovoltaic panels have been connected to two invertors, each 32 boards connected to one of the two used invertors. The system that used for this kind of photovoltaic panels is in-grid net metering system which have no batteries for storing the electricity. The total power of the used system is $20 \mathrm{kw}$, with productivity power of $100 \mathrm{kw} /$ day. Each photovoltaic panel generates $320 \mathrm{kw}$, during the observation it has been noticed that the orientation of the photovoltaic boards groups didn't matching the orientation of the building, the direction of the building was directly towards the north south direction, while the direction of the solar panels were oriented with 20 degree towards the east side. Continuous readings and measurements have been recorded, Table 1 shows the readings that collected from the day of installing this system on April 2015, up to one year after installation at Al-Dahriya municipality. 
Table 1. PV system readings.

\begin{tabular}{|c|c|c|c|c|c|c|c|c|c|c|}
\hline & Time & $\begin{array}{c}\text { Produced } \\
\text { PV system } \\
\text { meter } 1 \\
(100813030610)\end{array}$ & $\begin{array}{c}\text { Produced } \\
\text { PV system } \\
\text { meter } 2 \\
(100813030647)\end{array}$ & $\begin{array}{l}\text { PV export } \\
\text { to the grid } \\
(2.8 .0)\end{array}$ & $\begin{array}{l}\text { Municipality } \\
\text { building } \\
\text { consumption } \\
\text { meter }(1.8 .0)\end{array}$ & $\begin{array}{c}\text { Inverter } 1 \\
(304993273)\end{array}$ & $\begin{array}{c}\text { Inverter } 2 \\
(304993208)\end{array}$ & Total & Days & Radiation \\
\hline Date & & KW & KW & KW & KW & KW & KW & & & $\mathrm{KWh} /$ day $/ \mathrm{m}^{2}$ \\
\hline $11 / 04 / 2015$ & $1: 23 \mathrm{PM}$ & 1352 & 1360 & 531 & 4491 & 1368 & 1374 & 2742 & 27 & 5.077 \\
\hline $4 / 05 / 2015$ & 11:30AM & 2573 & 2572 & 1151 & 7760 & 2600 & 2598 & 2456 & 23 & 5.339 \\
\hline $1 / 06 / 2015$ & 9:30AM & 3952 & 3957 & 1808 & 11,765 & 3993 & 3957 & 2752 & 28 & 4.914 \\
\hline $1 / 07 / 2015$ & 11:20AM & 5360 & 5305 & 2293 & 15,750 & 5416 & 5356 & 2822 & 30 & 4.703 \\
\hline $1 / 08 / 2015$ & 9:30AM & 6686 & 6613 & 2788 & 20,246 & 6754 & 6675 & 2657 & 30 & 4.428 \\
\hline $2 / 09 / 2015$ & 10:30AM & 7889 & 7802 & 2981 & 27,589 & 7967 & 7873 & 2411 & 32 & 3.767 \\
\hline $1 / 10 / 2015$ & 9:00AM & 8816 & 8725 & 3128 & 33,793 & 8904 & 8803 & 1867 & 29 & 3.218 \\
\hline $1 / 11 / 2015$ & 13:00AM & 10,158 & 10,071 & 3511 & 38,993 & 10,240 & 10,161 & 2694 & 29 & 4.644 \\
\hline $3 / 12 / 2015$ & $11: 20 \mathrm{AM}$ & 11,290 & 11,240 & 3808 & 43,830 & 11,404 & 11,342 & 2345 & 32 & 3.664 \\
\hline $3 / 01 / 2016$ & $1: 20 \mathrm{PM}$ & 12,435 & 12,400 & 4096 & 51,475 & 12,562 & 12,514 & 2330 & 31 & 3.758 \\
\hline $2 / 02 / 2016$ & 8:51AM & 13,462 & 13,451 & 4311 & 59,968 & 13,602 & 13,576 & 2102 & 29 & 3.624 \\
\hline $1 / 03 / 2016$ & 10:00AM & 14,699 & 14,723 & 4761 & 66,288 & 14,852 & 14,861 & 2535 & 28 & 4.526 \\
\hline $2 / 04 / 2016$ & 1:30PM & 16,189 & 16,152 & 5323 & 71,506 & 16,322 & 16,342 & 2951 & 32 & 4.610 \\
\hline
\end{tabular}

The first raw represents the readings that have been recorded at the first day after system installation, which shows the generated power by the photovoltaic system that appears on the two meters which was $2742 \mathrm{kw}$, and $531 \mathrm{kw}$ was exported to the grid, with total generated power by the system at that day of 3273 $\mathrm{kw}$, while the consumed power by the building at the same day was $4491 \mathrm{kw}$, the solar radiation intensity was $5.07778 \mathrm{kwh} / \mathrm{day} / \mathrm{m}^{2}$. The cumulative values for the various measurements have been taken for a one year after installation the photovoltaic boards system, that cumulative values represent that the total consumed electricity by the main building was $71,506 \mathrm{kw}$, while the total generated power by the PV system that transferred to building was $32,664 \mathrm{kw}$, and $5323 \mathrm{kw}$ exported to the grid, that means the total generated power by PV system was $37,987 \mathrm{kw}$, the participation of energy that produced by the photovoltaic system is $53.12 \%$ of the total power demand of the building, the value of generated power was vary between the summer months (May to August) and winter months (October to February) through the difference of the solar radiation intensity and the number of shinning hours, the largest reading of solar radiation intensity was in the summer months as shown in Figure 2.

The lack of maintenance is decreasing the efficiency of photovoltaic panels, The PV panels should be continuously cleaned in order to obtain the maximum generated power, the presence of a dust on the PV panels will decrease the panels efficiency through decreasing the amount of received sunlight [13] [14] [15] [16]. According to Köntges, et al. 2014 [17], one of the famous failure is the glass 
breakage, which decrease the performance of PV panels on the long term. There are no recent readings for the PV system, which will lead to the weakness of the system follow up and decreasing of the monitoring efficiency of the system. To sum up, there are a numerous influence that affect the performance of PV panels, they are classified into two major groups, the first group is environmental factors such as: temperature, dust, and shadow, the second group is the installation factors such as: mismatch effects, and angle of inclination or orientation of PV panels, [18] integrates all the factors that affect the efficiency of PV panels and representing the losses of power that cased by each factor. The total area of the roof of main building is $650 \mathrm{~m}^{2}$, while the total area that used for the installed PV system is $100 \mathrm{~m}^{2}$ only, the reason of using this small area of the roof is the geometry and the orientation of the building, the angle between the photovoltaic boards and the building is large which decreases the number of used boards, despite of the previous, there are a good free space on the first level of roof that can be used to install at least 16 photovoltaic boards which will increase the generated power by the system and promote the energy efficiency in the building. The other buildings and utilities of the municipality have been studied through calculating the appropriate area for installing a new photovoltaic boards system that could be promote the energy efficiency in the municipality overall. Table 2 shows the total area for each utility and the proposed area that could be used for installing photovoltaic boards system.

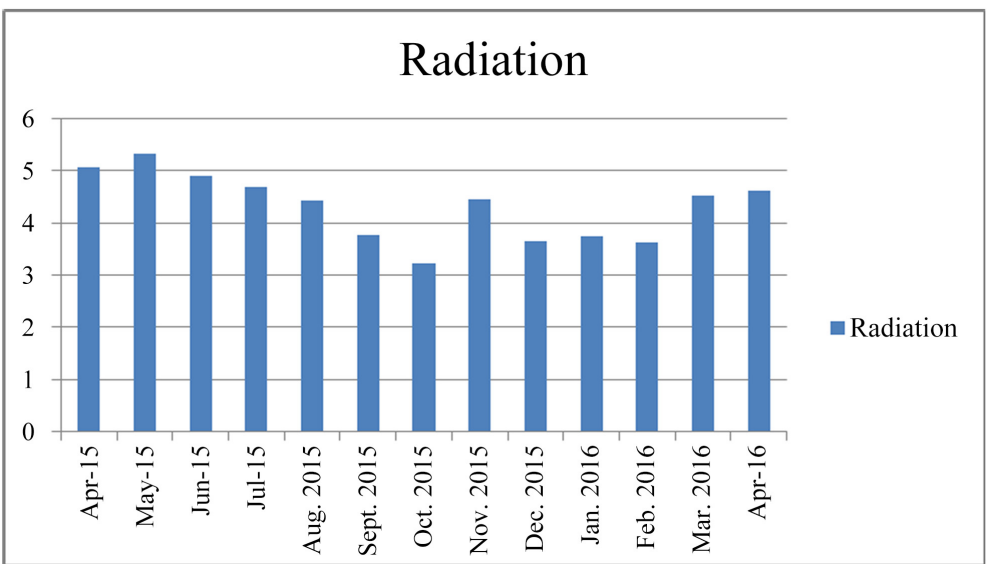

Figure 2. Solar radiation along the months at the site study.

Table 2. The suitable area for implementing PV system in municipality buildings.

\begin{tabular}{ccc}
\hline Building/utility & Total area $\left(\mathrm{m}^{2}\right)$ & Proposed area for PV system $\left(\mathrm{m}^{2}\right)$ \\
\hline The public park & 20,000 & 3500 \\
Entertainment complex & 13,000 & 3000 \\
Cars station & 500 & 500 \\
The cemetery & 7500 & 3000 \\
livestock market & 9500 & 5000
\end{tabular}


The total area of all utilities that could be used for installing the PV system was $15,000 \mathrm{~m}^{2}$, that means a good design for the system can use $10,000 \mathrm{~m}^{2}$ for the panels and the rest area for the service and maintenance, by using a new PV system with recent technology and high specification, a greater amount of power can be generated and used in order to promote energy efficiency in the municipality overall.

\subsection{Thermal Insulation}

The building sector is considered as the biggest single contributor to world energy consumption and greenhouse gas emissions. As a response to the increasing trend of energy use in buildings, decision makers and public authorities around the world adopted policies and measures aiming to reduce energy consumption and promote energy efficiency in buildings [7]. The decreasing of heat transfer through the boundary wall into the internal side of the building is an important issue to achieve the comfortable temperature inside the building. The heat transfers from the side with high temperature to the side with low temperature, the heat transfers from the hot atmosphere to the adjacent external side of boundary wall of the building by convection, and then it transfers to the internal side of the boundary wall by conduction, and finally it transfers to the surrounding air inside the room by convection. There are a lot of parameters that control the amount of heat transferred to inside the building, that parameters are: characteristics of the materials that used in wall layers, the thickness of each wall's layers, the surface area that subjected to heat transfer, and the temperature difference between inside and outside the building, Equation (1). illustrates the relationship between those variables and the amount of heat transferred, the methods and formulas that used for calculating heat transfer have been mentioned in Flori, et al. 2017 [19].

$$
Q=-K A \Delta T / \Delta X
$$

where $Q$ is the total heat transferred through the wall, $K$ is the thermal conductivity constant, $A$ is the surface area, $\Delta T$ is the temperature difference between the two-sides of boundary wall, and $\Delta X$ is the thickness of each layer of wall's layers. In order to find the total heat transferred $Q$ the value of each variable in the formula must be substituted, to determine the thermal conductivity constant $\mathrm{K}$ the components of the boundary wall materials must be known. The building materials that used in the most of buildings today are classical building materials that include stones, bricks, concrete, glass, wood, insulation materials, tiles, and plastic [20]. At the site of study, it noticed that the boundary wall of the main building of Al-Dahriya municipality consists of three layers, the layers from the external side to the internal side was as follows: building stone of $5 \mathrm{~cm}$ thickness, $25 \mathrm{~cm}$ of reinforced concrete, and $1 \mathrm{~cm}$ of internal plastering as shown in Figure 3.

The thermal conductivity constant $K$ for the wall layers are presented in Table 3. 


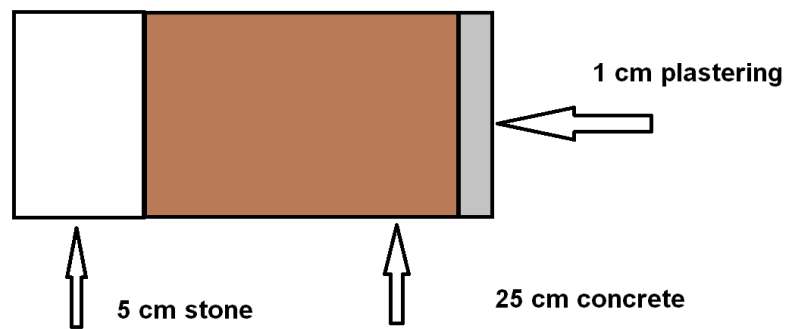

Figure 3. Al-Dahriya municipality wall layers.

Table 3. Thermal conductivity of typical building materials [21].

\begin{tabular}{cc}
\hline Material & $K(\mathrm{w} / \mathrm{m} k)$ \\
\hline concrete & 1.4 \\
plaster & 0.8 \\
Gypsum board & 0.16 \\
polystyrene & 0.032 \\
stone & 1.5 \\
\hline
\end{tabular}

The surface area $A$ is assumed to be $1 \mathrm{~m}^{2}$, and the temperature of the internal and external sides of the wall was measured, the temperature of the building stone at the external side of the wall $T_{1}$ was registered a value of $34^{\circ} \mathrm{C}$ as an average temperature of August which is the most warming month in Al-Dahriya as shown in Figure 4, this figure represents the gradient in colors from cool blue to hot red of the average monthly day and night temperatures in the site study from 1908 to 2018, and the internal temperature of the internal side of the wall $T_{2}$ assumed to be $24^{\circ} \mathrm{C}$ which is the comfortable temperature inside the buildings, where $\Delta T$ is $T_{2}-T_{1}$, by substituting the values in Equation (1), the total heat transferred from the external side of the wall to the internal side $Q_{1}$ can be achieved, the total $Q_{1}$ for one square meter equal to $37.45 \mathrm{w} / \mathrm{m}^{2}$.

The decreasing of using air conditioning system (AC) will increase the energy efficiency, According to Taras, 2017 [23], 39.5\% of the energy worldwide in 2016 was used to heat and cool the buildings. In order to decrease the usage of AC, selected thermal insulation materials must be added to the layers of the wall, the thermal insulation materials will decrease the heat transfer through the boundary wall. There are a lot of thermal insulation materials that could be used in to minimize the heat transfer through the walls in order to obtain a comfortable temperature inside the building, Abu-Jdayil, et al. 2019 [24] studied the thermal building insulation materials that have been used in the past decades, and the current insulation materials used, and concentrating on studying the cost, efficiency, and the impact of these insulations on the environment, in addition the light was shed on the renewable resources and wastes in thermal insulations development. The main building of municipality is already constructed and occupied, that's require to use selected thermal insulation materials that does not include new dirty civil works, the proposed thermal insulation materials were the 
using of $2 \mathrm{~cm}$ expanded polystyrene and $1.5 \mathrm{~cm}$ gypsum board which will be installed on the internal side of the boundary wall, Table 3, shows the value of thermal conductivity $K$ for the used thermal insulation materials. Schiavoni et al. 2016 [25] tabulated the various kinds of thermal insulation materials versus the material density, thermal conductivity, specific heat, and fire classification. By applying Equation (1), and substituting the values of temperature, thickness of layers, and the thermal conductivity of layers that used in calculating $Q_{1}$ and the new values for the added thermal insulation materials, the new total of heat transferred per one square meter $Q_{2}$ can be achieved, the value of $Q_{2}$ was equal to $10.14 \mathrm{w} / \mathrm{m}^{2}$. It could be seen that the applying of thermal insulation materials of $2 \mathrm{~cm}$ expanded polystyrene and $1.5 \mathrm{~cm}$ gypsum board will decrease the total heat transferred through the wall for one square meter by $27.31 \mathrm{w} / \mathrm{m}^{2}$, in other words, the heat transferred inside the building after adding the insulation layers is less than one third the total heat transferred through the wall before the applying of insulation system, which will decrease the depending on $\mathrm{AC}$ and hence promoting energy efficiency in the building, Figure 5, describes the insulation layers in the wall.

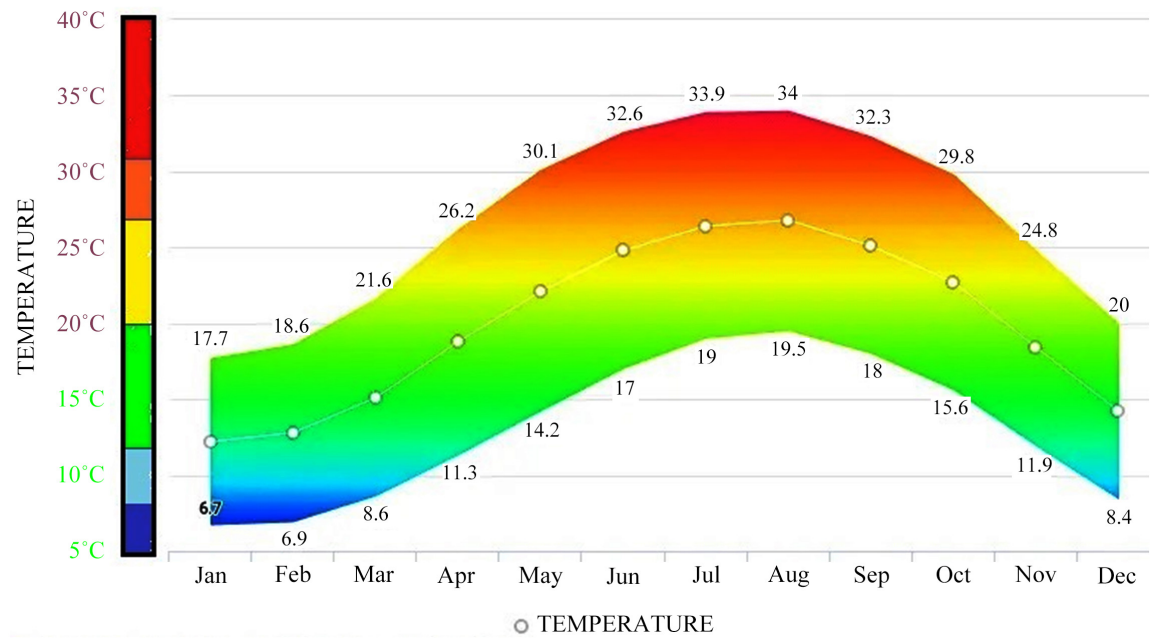

Figure 4. The average monthly day (top) and night (bottom) temperatures in Al Dahriya from 1908 to 2018 [22].

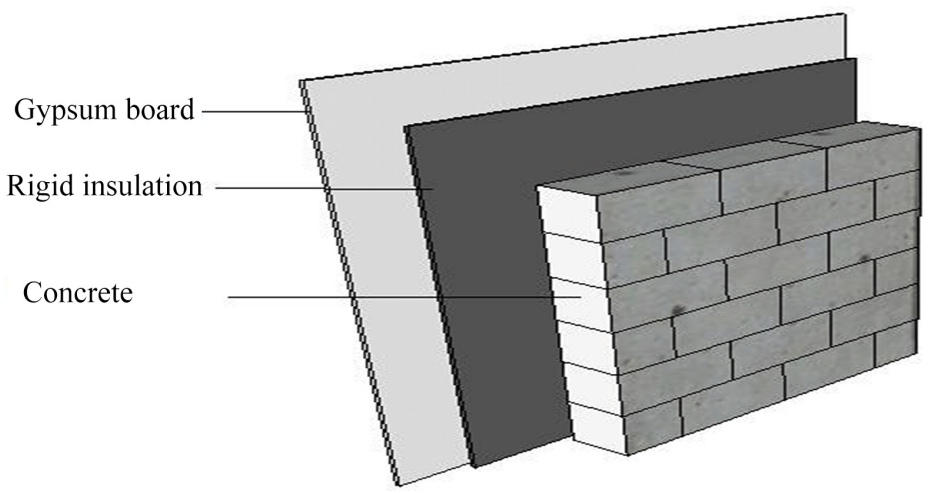

Figure 5. Insulation layers [26]. 
The glass that has been used in the building's windows is $4 \mathrm{~mm}$ single glass which allows the heat transfer easily through the window, using of double-glazed window with glass of more thickness and suitable gap between the two glass boards will decrease the heat transferred through the window. It was seen that thermal insulation materials that have been used in the building's walls, a $2 \mathrm{~cm}$ expanded polystyrene and $10 \mathrm{~cm}$ hollow concrete blocks will decrease the heat transfer through the boundary wall, the usage of thermal insulation materials in the recently constructed projects by municipality confirms the importance of applying this system in reducing power consumption and promoting energy efficiency in the building.

\section{Discussion}

Achieving optimal efficient energy system needs to have a wide planning, and clear vision regarding the importance of applying the renewable energy systems and using the thermal insulation materials in buildings construction. There are two major results that have been achieved through this study, the first result illustrates that applying photovoltaic panels system in the main building of Al-Dahriya municipality saves electricity up to around $50 \%$, the other result indicates that using of appropriate thermal insulation materials can saving the needed energy up to $70 \%$, this saving in electricity can be achieved through applying of the previous measures that will contribute in promoting energy efficiency in the building. Increasing employees awareness regarding the right use of municipality's facilities will increase the energy efficiency, this awareness includes closing the devices and instruments after finishing the work, turning the lights off during the non-using of facilities, and other measures that could be applied in order to decrease the electricity bill. Applying the mentioned energy efficiency measures would save surely considerable amounts in the electric energy bill and fuel, and encouraging other municipalities to apply the principle of promoting energy efficiency. The rapid development and new technologies in energy sector is to minimize the depending of using traditional energy sources and increasing the participation of renewable energy sources, LED light fittings and accessories, modern devices and instruments, and selected building materials have a large participation in promoting energy efficiency in the building. Promoting energy efficiency in buildings include lighting, heating, ventilation, and air conditioning (HVAC) end uses as well as motors, reflective roofs and a variety of other applications. Efficiency selections are made during initial design of the building, when equipment wears out and is replaced, or during efficiency upgrades that can occur at any time [27]. Referring to the new technologies, different types of photovoltaic panels have been produced, the specification of those new PV panels gives more energy generation with minimum size of these panels, for example the generated energy by the used PV panels in the main building of municipality is $320 \mathrm{kw}$, while the new technologies that used in producing new PV panels with high efficiency in the market nowadays gives $580 \mathrm{kw}$ 
of produced energy with the same size of the PV panels that used now in the municipality, which will give the maximum energy with the minimum area needed for installing this system. The technologies that related in improving building materials and thermal insulation materials have also growing rapidly, a lightweight material with high limit of thermal insulation are available in the market with a competitive prices. There are a lot of barriers that facing the municipalities in order to promote energy efficiency in the buildings, the barriers that facing the institutions in the developing countries are relatively the same, according to Painuly, et al., 2003 [28]. Developing countries have tremendous potential to increase energy efficiency but face several barriers before the potential can be realized. A lack of access to appropriate financing mechanisms is one of the important barriers.

The municipality is recommended to install a set of $16 \mathrm{PV}$ panels on the west side of the first roof of main building, which will provide extra generated energy to the system, the continuous cleaning of the installed PV panels and the replacement of broken boards will increase the energy efficiency that generated by the system, using of recent PV panels with new technology and high efficiency in the other buildings and utilities of municipality will decrease the value of electricity bill more than the half.

\section{Conclusion}

A lot of aspects that could promote energy efficiency in the buildings must be studied in the future, some of aspects haven't conducted in this work such as the effect of using LED lights instead of existing lights, using instruments and devices with new technologies that saving power, and using the electronic control of the lights. Tan, et al. 2016 [29] reported that the replacing of used instruments and devices by a more energy efficient one by using the new technologies will reduce $\mathrm{CO}_{2}$ emissions as well as decrease the energy consumption. Future study of replacing the split unit of air conditioning system by central heating system or using chillers is an important way, in order to measure the saved energy by this replacement, According to Connolly, et al., 2014 [30], heating of buildings including the achievement of hot water for domestic usage consumed around 23\% of the total demand of energy. Al-Dahriya municipality is encouraged to do like those studies in order to minimize the electricity bill and promote energy efficiency overall the municipality buildings and utilities. Further studies can be conducted in order to promote energy efficiency in Al-Dahriya municipality, replacing the current lights fittings and fixtures with led lights, and applying an automatic lighting system that could rise the energy efficiency significantly.

\section{Acknowledgements}

The authors would like to gratefully acknowledge Eng. Yousef Shroukh for his help and Al-Dahriya Municipality management for their permission to conduct the study. 


\section{Conflicts of Interest}

The authors declare no conflicts of interest regarding the publication of this paper.

\section{References}

[1] Congress, U. (1992) Office of Technology Assessment, Building Energy Efficiency.

[2] Gielen, D., Boshell, F., Saygin, D., Bazilian, M.D., Wagner, N. and Gorini, R. (2019) The Role of Renewable Energy in the Global Energy Transformation. Energy Strategy Reviews, 24, 38-50. https://doi.org/10.1016/j.esr.2019.01.006

[3] Alsamamra, H., and Shoqier, J. (2020) Assessment of Wind Power Potential at Eastern-Jerusalem, Palestine. Open Journal of Energy Efficiency, 9, 131-149. https://doi.org/10.4236/ojee.2020.94009

[4] Khaldi, Y.M. and Sunikka-Blank, M. (2020) Governing Renewable Energy Transition in Conflict Contexts: Investigating the Institutional Context in Palestine. Energy Transitions, 4, 69-90. https://doi.org/10.1007/s41825-020-00024-Z

[5] Vine, E. (2003) Opportunities for Promoting Energy Efficiency in Buildings as an Air Quality Compliance Approach. Energy, 28, 319-341. https://doi.org/10.1016/S0360-5442(02)00112-3

[6] Vigna, I., Pernetti, R., Pasut, W. and Lollini, R. (2018) New Domain for Promoting Energy Efficiency: Energy Flexible Building Cluster. Sustainable Cities and Society, 38, 526-533. https://doi.org/10.1016/j.scs.2018.01.038

[7] Allouhi, A., El Fouih, Y., Kousksou, T., Jamil, A., Zeraouli, Y. and Mourad, Y. (2015) Energy Consumption and Efficiency in Buildings: Current Status and Future Trends. Journal of Cleaner Production, 109, 118-130. https://doi.org/10.1016/j.jclepro.2015.05.139

[8] Manfren, M., Caputo, P. and Costa, G. (2011) Paradigm Shift in Urban Energy Systems through Distributed Generation: Methods and Models. Applied Energy, 88, 1032-1048. https://doi.org/10.1016/j.apenergy.2010.10.018

[9] Popescu, D., Bienert, S., Schützenhofer, C. and Boazu, R. (2012) Impact of Energy Efficiency Measures on the Economic Value of Buildings. Applied Energy, 89, 454-463. https://doi.org/10.1016/j.apenergy.2011.08.015

[10] Maidment, C.D., Jones, C.R., Webb, T.L., Hathway, E.A. and Gilbertson, J.M. (2014) The Impact of Household Energy Efficiency Measures on Health: A Meta-Analysis. Energy Policy, 65, 583-593. https://doi.org/10.1016/j.enpol.2013.10.054

[11] Jayakumar, P. (2009) Resource Assessment Handbook. Asia and Pacific Center for Transfer of Technology of the United Nations, Economic and Social Commission for Asia and the Pacific (ESCAP).

[12] Ibrik, I.H. and Mahmoud, M.M. (2005) Energy Efficiency Improvement Procedures and Audit Results of Electrical, Thermal and Solar Applications in Palestine. Energy Policy, 33, 651-658. https://doi.org/10.1016/j.enpol.2003.09.008

[13] Meral, M.E. and Dincer, F. (2011) A Review of the Factors Affecting Operation and Efficiency of Photovoltaic Based Electricity Generation Systems. Renewable and Sustainable Energy Reviews, 15, 2176-2184. https://doi.org/10.1016/j.rser.2011.01.010

[14] Saidan, M., Albaali, A.G., Alasis, E. and Kaldellis, J.K. (2016) Experimental Study on the Effect of Dust Deposition on Solar Photovoltaic Panels in Desert Environment. 
Renewable Energy, 92, 499-505. https://doi.org/10.1016/j.renene.2016.02.031

[15] Maghami, M.R., Hizam, H., Gomes, C., Radzi, M.A., Rezadad, M.I. and Hajighorbani, S. (2016) Power Loss Due to Soiling on Solar Panel: A Review. Renewable and Sustainable Energy Reviews, 59, 1307-1316.

https://doi.org/10.1016/j.rser.2016.01.044

[16] Zaihidee, F.M., Mekhilef, S., Seyedmahmoudian, M. and Horan, B. (2016) Dust as an Unalterable Deteriorative Factor Affecting PV Panel's Efficiency: Why and How. Renewable and Sustainable Energy Reviews, 65, 1267-1278. https://doi.org/10.1016/j.rser.2016.06.068

[17] Köntges, M., Kurtz, S., Packard, C., Jahn, U., Berger, K.A., Kato, K., Wohlgemuth, J., et al. (2014) Review of Failures of Photovoltaic Modules.

[18] Fouad, M., Shihata, L.A. and Morgan, E.I. (2017) An Integrated Review of Factors Influencing the Performance of Photovoltaic Panels. Renewable and Sustainable Energy Reviews, 80, 1499-1511. https://doi.org/10.1016/j.rser.2017.05.141

[19] Flori, M., Puțan, V. and Vîlceanu, L. (2017) Using the Heat Flow Plate Method for Determining Thermal Conductivity of Building Materials. The IOP Conference Series: Materials Science and Engineering, 163, Article ID: 012018.

https://doi.org/10.1088/1757-899X/163/1/012018

[20] Khitab, A. (2016) Classical Building Materials. IGI Global, Hershey. https://doi.org/10.4018/978-1-5225-0344-6.ch001

[21] WiKi, D.B. (2020) Thermal Conductivity of Building Materials.

[22] www.hikersbay.com (2018) Average Monthly Temperature of Al-Dahriya Town.

[23] Taras, V. (2017) Foreign Energy Trading as a Factor of Economic Security of Ukraine. Strategic Priorities, 43, 113-119.

[24] Abu-Jdayil, B., Mourad, A.-H., Hittini, W., Hassan, M. and Hameedi, S. (2019) Traditional, State-of-the-Art and Renewable Thermal Building Insulation Materials: An Overview. Construction and Building Materials, 214, 709-735.

https://doi.org/10.1016/j.conbuildmat.2019.04.102

[25] Schiavoni, S., Bianchi, F. and Asdrubali, F. (2016) Insulation Materials for the Building Sector: A Review and Comparative Analysis. Renewable and Sustainable Energy Reviews, 62, 988-1011. https://doi.org/10.1016/j.rser.2016.05.045

[26] Al-zubaidy, A. (2013) Small Size Office Building Construction Layers for External Wall.

[27] Jackson, J. (2010) Promoting Energy Efficiency Investments with Risk Management Decision Tools. Energy Policy, 38, 3865-3873. https://doi.org/10.1016/j.enpol.2010.03.006

[28] Painuly, J.P., Park, H., Lee, M.-K. and Noh, J. (2003) Promoting Energy Efficiency Financing and ESCOs in Developing Countries: Mechanisms and Barriers. Journal of Cleaner Production, 11, 659-665. https://doi.org/10.1016/S0959-6526(02)00111-7

[29] Tan, B., Yavuz, Y., Otay, E.N. and Çamlıbel, E. (2016) Optimal Selection of Energy Efficiency Measures for Energy Sustainability of Existing Buildings. Computers \& Operations Research, 66, 258-271. https://doi.org/10.1016/j.cor.2015.01.013

[30] Connolly, D., Lund, H., Mathiesen, B.V., Werner, S., Möller, B., Persson, U. and Nielsen, S. (2014) Heat Roadmap Europe: Combining District Heating with Heat Savings to Decarbonise the EU Energy System. Energy Policy, 65, 475-489. https://doi.org/10.1016/j.enpol.2013.10.035 